\title{
Senyawa pada Serbuk Rimpang Kunyit (Curcuma longa L.) yang Berpotensi sebagai Antioksidan
}

\section{Compounds in Turmeric Rhizome Powder (Curcuma longa L.) which have Potential as Antioxidants}

\author{
Teguh Suprihatin ${ }^{1 *}$, Sri Rahayu ${ }^{2}$, Muhaimin Rifa'i ${ }^{2}$, Sri Widyarti ${ }^{2}$ \\ ${ }^{1}$ Departemen Biologi, Fakultas Sains dan Matematika, Universitas Diponegoro, Semarang. \\ ${ }^{2}$ Jurusan Biologi, Fakultas Matematika dan Ilmu Pengetahuan Alam, Universitas Brawijaya, Malang. \\ *Email: teguhsuprihatin@lecturer.undip.ac.id
}

Diterima 20 Januari 2020 / Disetujui 4 Februari 2020

\begin{abstract}
ABSTRAK
Tanaman kunyit secara tradisional sudah sejak lama banyak digunakan sebagai tanaman obat. Negara India dan China menggunakan tanaman kunyit untuk mengobati penyakit empedu, selesma, batuk, diabetes, rematik, sinusitis, penyakit kulit, infeksi parasit, inflamasi, dan biliary disorders. Potensi tanaman kunyit sebagai tanaman obat menimbulkan ide untuk melakukan penelitian yang bertujuan mengetahui kandungan senyawa pada serbuk rimpang kunyit yang berpotensi sebagai antioksidan. Penelitian dilakukan dengan menganalisis kandungan senyawa pada serbuk rimpang kunyit (turmeric powder) menggunakan metode LC-MS dan dilanjutkan dengan menganalisis senyawa yang terkandung pada serbuk rimpang kunyit yang berpotensi sebagai antioksidan dengan metode in silico. Hasil penelitian menunjukkan bahwa terdapat 49 senyawa aktif yang ditemukan pada serbuk rimpang kunyit, kurkumin adalah senyawa dengan konsentrasi paling tinggi dibandingkan dengan senyawa yang lain yaitu sebesar 7,798\%. Sedangkan senyawa yang berpotensi sebagai antioksidan berdasarkan analisis in silico diperoleh 11 senyawa yaitu Ascorbic acid, Quercetin, $\beta$ Carotene, Arabinose, Bis Demethoxycurcumin, Demethoxycurcumin, Curcumin, Caffeic acid, Cinnamic acid, Letestuianin A, dan Calebin A.
\end{abstract}

Kata kunci: turmeric powder, kurkumin, LC-MS, in silico

\begin{abstract}
Turmeric have used as a traditional medicinal plant for a long time. India and China have used turmeric to tread bile disease, cough, diabetes, sinusitis, skin disease, parasites infection, inflammation, and biliary disorders. The potential of turmeric as a medicinal plant raises the idea to conduct research aimed at finding out the content of compounds in turmeric rhizome powder which have the potential as antioxidants. The study was conducted by analyzing the content of compounds in turmeric using the LC-MS method and proceed by analyzing the compounds contained in turmeric rhizome powder which have the potential as antioxidants with the in silico method. The results showed that there were 49 active compounds found in turmeric rhizome powder, curcumin was the compound with the highest concentration compared to other compounds which was $7.798 \%$. While compounds that have potential as antioxidants based on in silico analysis obtained 11 compounds namely Ascorbic acid, Quercetin, $\beta$ Carotene, Arabinose, Bis Demethoxycurcumin, Demethoxycurcumin, Curcumin, Caffeic acid, Cinnamic acid, Letestuianin A, and Calebin A.
\end{abstract}

Keywords: turmeric powder, curcumin, LC-MS, in silico.

\section{PENDAHULUAN}

Tanaman kunyit adalah tanaman herba perenial dan mempunyai rizoma (rimpang/umbi) yang masuk ke dalam famili jahe (Zingiberaceae). Tanaman kunyit merupakan tanaman tropis asli dari
Asia dan sekarang sudah menyebar ke daerahdaerah subtropis di seluruh dunia (Li et al., 2011). Serbuk berwarna kuning gelap yang dihasilkan dari rimpang kunyit dikenal dengan nama turmeric powder, di India, China dan Asia sudah sejak lama 
banyak digunakan untuk bahan makanan dan pengobatan (Singh et al., 2010).

Tanaman kunyit dewasa ini banyak dibudidayakan karena secara tradisional dipercaya dapat mengobati berbagai penyakit. Di India serbuk kunyit digunakan untuk mengobati penyakit empedu, selesma, batuk, diabetes, penyakit hepatik, rematik dan sinusitis (Singh et al., 2010). Pengobatan tradisional China menggunakan serbuk kunyit untuk mengobati penyakit kulit, infeksi parasit, inflamasi, rematik, dan biliary disorders $(\mathrm{Li}$ et al., 2011).

Komponen kimia pada rimpang kunyit menurut penelitian Li et al., (2011) adalah komponen fenolik yaitu diarylheptanoids dan diarylpentanoids, kurkumin $\left(\mathrm{C}_{21} \mathrm{H}_{20} \mathrm{O}_{5}\right)$ termasuk golongan diarylheptanoids (fenol), rimpang kunyit mengandung kurkumin dan turunannya sebesar 315\% (kurkumin 71,5\%, demetoksikurkumin 19,4\% dan bisdemetoksikurkumin 9,1\%). Kandungan kimia berikutnya adalah fenilpropen dan komponen fenolik lain seperti terpen yaitu monoterpen, sesquiterpen, diterpen, triterpen, alkaloid, steroids, dan asam lemak (Aggarwal et al., 2006).

Berdasarkan hasil penelitian Balai Penelitian Tanaman Rempah dan Obat (Balittro) bahwa kandungan kurkumin rimpang kunyit rata-rata 10,92\% (Simanjuntak, 2011). Hasil penelitian Asghari et al. (2008), menyatakan bahwa pada pemanenan usia tanaman kunyit 10 bulan, akan diperoleh rimpang kunyit dengan berat rata-rata 6,30g dari setiap satu pokok tanaman kunyit, dan rata-rata kandungan kurkumin sebanyak $170,1 \mathrm{mg}$ atau sebesar 2,7\%. Serbuk kering rimpang kunyit (turmeric) mengandung 3-5\% kurkumin dan dua senyawa derivatnya dalam jumlah yang kecil yaitu demetoksikurkumin dan bisdemetoksikurkumin, yang ketiganya sering disebut sebagai kurkuminoid (Singh et al., 2010).

Kandungan kurkuminoid menjadi dasar penilaian kualitas rimpang kunyit, semakin tinggi kandungan kurkuminoid dalam rimpang atau serbuk kunyit maka semakin tinggi nilai ekonomisnya (Li et al., 2011). Kurkumin murni di pasaran komersial tersedia dalam bentuk campuran dengan kedua turunannya yaitu demetoksikurkumin dan bisdemetoksikurkumin, yang berupa senyawa kurkuminoid. Kandungan kurkumin dalam rimpang kunyit bervariasi sesuai dengan jenis tanaman kunyit (kultivar), usia pemanenan, ukuran atau jenis rimpang (rimpang induk kandungan kurkumin berbeda dengan rimpang anakan), dan kondisi tanah (daerah, iklim, musim) (Asghari et al., 2009). Kandungan kurkumin pada kunyit (Curcuma longa) adalah $3-8 \%$, paling tinggi dibandingkan dengan kunyit putih (Curcuma zedoaria) 0,1\%, dan temu lawak (Curcuma xanthorrhiza) 1,2\% (Chattopadhyay et al., 2004). Kurkumin dapat diekstraksi dari rimpang kunyit dengan menggunakan berbagai teknik seperti hidrodestilasi, low pressure solvent extraction, soxhlet, dan supercritical fluid extraction (SFE) (Li et al., 2011).

Kurkumin saat ini telah dapat dibuat senyawa analognya dengan melakukan modifikasi pada gugus aromatik terminal dan metilen aktif. Salah satu senyawa analog kurkumin yang telah mendapat hak paten sebagai antioksidan dan diperkenalkan sebagai Molekul Nasional (Molnas) adalah pentagamavunon-O atau $P G V-O \quad\left(\left(2,5\right.\right.$ bis $\left(4^{\prime}\right.$ hidroksi-3'-metoksi benzilidin) siklopentanon)) (Purwaningsih dkk., 2013). Kurkumin diyakini memodulasi beberapa molekuler target dan menghambat faktor transkripsi $(N F-k B)$, enzim (COX-1, COX-2, LOX), sitokin (TNF $\alpha, I L-1 \beta, I L-6)$ dan gen-gen antiapoptotik (BCL2, BCL2L1) (Shehzad and Lee, 2010).

Ekstrak serbuk rimpang kunyit atau bahan aktif kurkuminoid juga menunjukkan aktivitas hepatoprotektif, kardioprotektif, antifungal, dan antioksidan. Penelitian in vivo dan in vitro serta percobaan secara klinis di China dan USA menduga bahwa kurkumin adalah salah satu komponen yang paling dianjurkan untuk dikembangkan dalam terapi penyakit Alzheimer's (Hamaguchi et al., 2010). Hasil penelitian Kohli et al., (2005), menyatakan bahwa kurkumin mempunyai aktivitas antioksidan, scavenger superoksida dan menghambat peroksidasi lipid. Selain itu kurkumin juga dianggap mempunyai fungsi sebagai pembersih oksigen reaktif spesies dan nitrogen reaktif spesies, atau bertanggungjawab melindungi DNA terhadap kerusakan yang disebabkan oleh radikal bebas dan melindungi hepatosit dari berbagai racun. 
Hasil penelitian sebelumnya telah banyak menyebutkan tentang fungsi serbuk rimpang kunyit dalam pengobatan herbal, salah satunya adalah fungsi serbuk rimpang kunyit sebagai antioksidan. Penelitian ini bertujuan untuk mengetahui senyawa yang terdapat pada serbuk rimpang kunyit dengan melakukan uji LC-MS (Liquid ChromatographyMass Spectrometry) pada serbuk rimpang kunyit dan dilanjutkan dengan analisis in silico menggunakan program PASS Server Prediction untuk mengetahui nilai Probability Activity dari senyawa-senyawa yang terdapat pada serbuk rimpang kunyit hasil dari uji $L C-M S$.

\section{METODE PENELITIAN}

Serbuk Rimpang kunyit diperoleh dari Laboratorium Balai Penelitian Tanaman Rempah dan Obat (Balittro), Jl. Tentara Pelajar no. 3 Bogor. Rimpang kunyit dipanen dari tanaman kunyit yang telah berusia sekitar 8 bulan, dipilih rimpang utama dengan panjang sekitar $5-7 \mathrm{~cm}$ dan diameter 1 $1,5 \mathrm{~cm}$. Rimpang kunyit dibersihkan dengan dicuci menggunakan air sampai bersih kemudian diiris tipis dan dikering-anginkan sampai kering. Pengeringan dilakukan selama kurang lebih 2 minggu sampai kandungan air hanya tinggal sekitar 10\% (Asghari et al., 2008). Irisan tipis rimpang kunyit yang sudah kering kemudian diblender sampai terbentuk serbuk rimpang kunyit (turmeric). Selanjutnya dilakukan pengayakan pada serbuk rimpang kunyit dengan menggunakan ayakan yang berukuran 200mesh.

Serbuk rimpang kunyit dimaserasi dengan pelarut $\mathrm{n}$-heksana hingga filtratnya jernih. Filtrat kemudian disaring, residunya dikering-anginkan sampai kering. Residu yang telah kering kemudian dimaserasi kembali menggunakan etanol hingga filtratnya jernih. Ekstrak yang diperoleh kemudian dipekatkan dengan rotary evaporator sampai diperoleh ekstrak berbentuk bubuk.

Analisis $L C-M S$ dilakukan dengan cara sampel (bubuk) dilarutkan dengan etanol HPLC grade sehingga menjadi $10 \mathrm{mg} / \mathrm{mL}$. Kemudian dilanjutkan dengan menginjeksikan 100uL larutan dalam sistem instrumentasi Shimadzu 2010A yang menggunakan kolom Phenomenex Luna RP-C $(150 \times 2 \mathrm{~mm})$ dengan fasa gerak gradien dari $10 \%$ asetonitril-air hingga 100\% asetonitril-air selama 40 menit. Proses determinasi rumus molekul senyawa yang terdapat pada sampel akan ditampilkan dalam bentuk kromatogram (Setyaningsih dkk., 2016).

Hasil analisis $L C-M S$ yang berupa kandungan senyawa-senyawa dari serbuk rimpang kunyit selanjutnya dilakukan analisis in silico untuk mengetahui potensinya sebagai antioksidan. Analisis menggunakan program PASS server prediction, dimana akan diperoleh nilai $P a$ dari masing-masing senyawa. Nilai $\mathrm{Pa}$ (Probability Activity) merupakan nilai yang menggambarkan potensi suatu senyawa yang diuji (Paramashivam et al., 2015). Penentuan nilai ini dilakukan dengan cara membandingkan struktur senyawa serbuk rimpang kunyit yang diinput dengan senyawa yang telah terbukti sebagai antioksidan. Senyawasenyawa pada serbuk rimpang kunyit memiliki nilai yang bervariasi, dengan interpretasi sebagai berikut :

1. Apabila nilai $P a$ lebih dari 0,7 menandakan bahwa senyawa tersebut diprediksi memiliki potensi yang tinggi sebagai antioksidan secara komputasi maupun uji laboratorium.

2. Sedangkan apabila nilai $\mathrm{Pa}$ lebih dari 0,3 namun kurang dari 0,7 maka senyawa tersebut secara komputasi memiliki kemampuan sebagai antioksidan, namun secara uji laboratorium perlu dibuktikan lebih lanjut

\section{HASIL DAN PEMBAHASAN}

Hasil analisis LC-MS (Liquid Chromatography-Mass Spectrometry) atau kromatrografi cair-spektrometri massa, pada serbuk rimpang kunyit diperoleh sebanyak 49 senyawa. Konsentrasi senyawa paling tinggi yang terkandung pada serbuk rimpang kunyit adalah kurkumin $\left(\mathrm{C}_{21} \mathrm{H}_{20} \mathrm{O}_{6}\right)$ yaitu $7,798 \%$, sedangkan konsentrasi untuk senyawa turunan kurkumin yaitu demethoksikurkumin $\left(\mathrm{C}_{20} \mathrm{H}_{18} \mathrm{O}_{5}\right)$ dan bis demethoksikurkumin $\left(\mathrm{C}_{19} \mathrm{H}_{16} \mathrm{O}_{4}\right)$ adalah $4,115 \%$ dan $2,277 \%$. Senyawa-senyawa yang terdapat pada serbuk rimpang kunyit berdasarkan hasil analisis $L C-M S$ disajikan pada Gambar 1 dan Tabel 1. 
Hasil analisis $L C-M S$ serbuk rimpang kunyit yang telah dilakukan sudah sesuai dengan hasil penelitian dari beberapa peneliti sebelumnya yang menyatakan bahwa serbuk rimpang kunyit mengandung senyawa fitokimia yang bervariasi termasuk kurkumin, demetoksikurkumin, bis demetoksikurkumin, zingiberen, curcumenol, turmeron, dan turmeronol (Chattopadhyay et al., 2004).
Kurkuminoid dan minyak esensial adalah bioaktif utama yang ditemukan pada tanaman kunyit, dengan kurkuminoid paling banyak terakumulasi pada bagian rimpang dari tanaman kunyit (Li et al., 2011). Kurkuminoid adalah sebutan untuk senyawa kurkumin beserta dengan turunannya (Chattopadhyay et al., 2004).

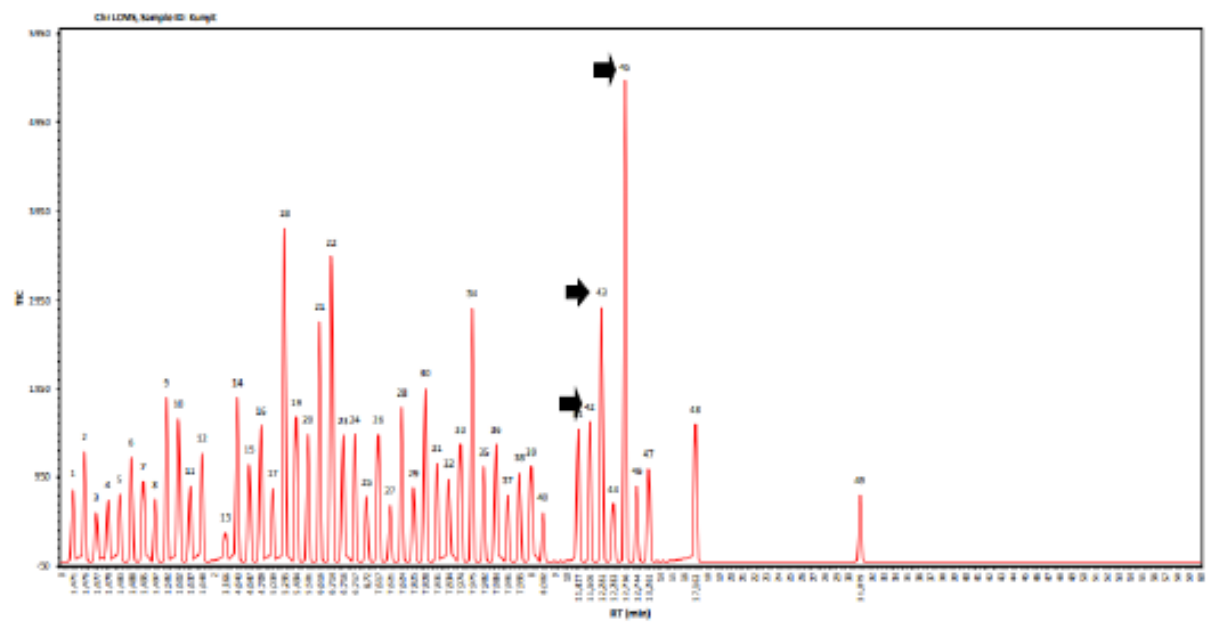

Gambar 1. Hasil analisis $L C$-MS serbuk rimpang kunyit dengan kandungan utama adalah kurkumin dengan nomor puncak (45), demetoksikurkumin (43), dan bis demetoksikurkumin (42) seperti terlihat pada tanda panah.

Faktor - faktor yang mempengaruhi kandungan senyawa yang terdapat pada rimpang tanaman kunyit beserta konsentrasinya adalah masa pemanenan rimpang kunyit, jenis kultivar tanaman kunyit (Asghari et al., 2009), metode pengeringan rimpang kunyit (Lokhande et al., 2013), dan kondisi rimpang kunyit yang akan dianalisis dalam kondisi segar atau kering (Singh et al., 2010). Kandungan kurkumin beserta turunannya yang terdapat pada rimpang tanaman kunyit mempunyai fungsi yang sangat beragam termasuk sebagai analgesik, antiseptik, antiinflamasi, antimalaria, dan antioksidan (Chattopadhyay et al., 2004).

Analisis pada kandungan senyawa serbuk rimpang kunyit yang berpotensi sebagai antioksidan berdasarkan nilai Probability activity (Pa score) dengan menggunakan program PASS server prediction terdapat pada Tabel 2. Hasil analisis menunjukkan bahwa terdapat 11 senyawa yang mempunyai nilai $P a>0,3$ yaitu Ascorbic acid, Quercetin, $\beta$ Carotene, Arabinose, Bis
Demethoxycurcumin, Demethoxycurcumin, Curcumin, Caffeic acid, Cinnamic acid, Letestuianin A, dan Calebin A. Nilai Pa diatas 0,3 dapat dikategorikan bahwa senyawa tersebut mempunyai aktivitas biologi dalam tubuh seperti yang dimaksud, dalam hal ini adalah potensi sebagai antioksidan.

Prediksi potensi kurkumin dan senyawa lain yang terkandung pada serbuk rimpang kunyit sebagai sebagai antioksidan adalah menjadi aktivator dari Nrf2. Nrf2 (Nuclear Related Factor 2) adalah faktor transkripsi yang berikatan dengan represor spesifik yaitu Keap1. Nrf2 dapat aktif apabila tidak berikatan dengan Keapl, obat-obatan komersial telah banyak dikembangkan untuk mengaktifkan Nrf2 dengan cara menghambat Keap1. Aktifnya Nrf2 yang tidak berikatan dengan Keap1 adalah representasi dari dimulainya sintesis enzim antioksidatif dalam upaya pencegahan stres oksidatif dan aging pada sel (Bruns et al., 2015). 
Tabel 1. Kandungan senyawa hasil analisis $L C-M S$ pada serbuk rimpang kunyit

\begin{tabular}{|c|c|c|c|c|c|}
\hline $\begin{array}{l}\text { Nomor } \\
\text { puncak }\end{array}$ & Nama senyawa & Rumus kimia & $\begin{array}{c}\text { Waktu retensi } \\
\text { (menit) }\end{array}$ & $\begin{array}{c}\text { Konsentrasi } \\
(\%)\end{array}$ & Nilai $\mathrm{m} / \mathrm{z}$ \\
\hline 1 & $\rho$ Cymene & $\mathrm{C}_{10} \mathrm{H}_{16}$ & 1,471 & 1,176 & 134.1096 \\
\hline 2 & $\alpha$ Terpinene & $\mathrm{C}_{10} \mathrm{H}_{16}$ & 1,476 & 1,790 & 136.1252 \\
\hline 3 & $\alpha$ Pinene & $\mathrm{C}_{10} \mathrm{H}_{16}$ & 1,477 & 0,791 & 136.1252 \\
\hline 4 & $\beta$ Pinene & $\mathrm{C}_{10} \mathrm{H}_{16}$ & 1,479 & 0,999 & 136.1252 \\
\hline 5 & Sabinene & $\mathrm{C}_{10} \mathrm{H}_{16}$ & 1,483 & 1,099 & 136.1252 \\
\hline 6 & Limonene & $\mathrm{C}_{10} \mathrm{H}_{16}$ & 1,488 & 1,705 & 136.1252 \\
\hline 7 & $\alpha$ Phellandrene & $\mathrm{C}_{10} \mathrm{H}_{16}$ & 1,495 & 1,306 & 136.1252 \\
\hline 8 & Camphene & $\mathrm{C}_{10} \mathrm{H}_{16}$ & 1,497 & 1,019 & 136.1252 \\
\hline 9 & Cinnamic acid & $\mathrm{C}_{9} \mathrm{H}_{8} \mathrm{O}_{2}$ & 1,582 & 2,676 & 148.0524 \\
\hline 10 & Arabinose & $\mathrm{C}_{5} \mathrm{H}_{10} \mathrm{O}_{5}$ & 1,602 & 2,313 & 150.0528 \\
\hline 11 & Linalool & $\mathrm{C}_{10} \mathrm{H}_{18} \mathrm{O}$ & 1,637 & 1,235 & 154.1358 \\
\hline 12 & $\alpha$ Terpineol & $\mathrm{C}_{10} \mathrm{H}_{18} \mathrm{O}$ & 1,648 & 1,755 & 154.1358 \\
\hline 13 & Ascorbic acid & $\mathrm{C}_{6} \mathrm{H}_{8} \mathrm{O}_{6}$ & 3,166 & 0,472 & 176.0321 \\
\hline 14 & Caffeic acid & $\mathrm{C}_{9} \mathrm{H}_{8} \mathrm{O}_{4}$ & 4,643 & 2,675 & 180.0423 \\
\hline 15 & Fructose & $\mathrm{C}_{6} \mathrm{H}_{12} \mathrm{O}_{6}$ & 4,647 & 1,578 & 180.0634 \\
\hline 16 & Glucose & $\mathrm{C}_{6} \mathrm{H}_{12} \mathrm{O}_{6}$ & 4,709 & 2,214 & 180,0634 \\
\hline 17 & Heptan 3 one & $\mathrm{C}_{12} \mathrm{H}_{18} \mathrm{O}_{2}$ & 5,039 & 1,190 & 194.1307 \\
\hline 18 & Curcumene & $\mathrm{C}_{15} \mathrm{H}_{22}$ & 5,295 & 5,411 & 202.1722 \\
\hline 19 & $\beta$ Caryophyllene & $\mathrm{C}_{15} \mathrm{H}_{24}$ & 5,494 & 2,350 & 204.1878 \\
\hline 20 & sesquiphellandrene & $\mathrm{C}_{15} \mathrm{H}_{24}$ & 5,501 & 2,072 & 204,1878 \\
\hline 21 & Ar Turmerone & $\mathrm{C}_{15} \mathrm{H}_{20} \mathrm{O}$ & 6,616 & 3,898 & 216.1514 \\
\hline 22 & $\alpha$ Turmerone & $\mathrm{C}_{15} \mathrm{H}_{22} \mathrm{O}$ & 6,714 & 4,949 & 218.1671 \\
\hline 23 & Bisacumol & $\mathrm{C}_{15} \mathrm{H}_{22} \mathrm{O}$ & 6,716 & 2,050 & 218.1671 \\
\hline 24 & Curlone & $\mathrm{C}_{15} \mathrm{H}_{22} \mathrm{O}$ & 6,717 & 2,078 & 218.1671 \\
\hline 25 & $\alpha$ Atlantone & $\mathrm{C}_{15} \mathrm{H}_{22} \mathrm{O}$ & 6,720 & 1,064 & 218.1671 \\
\hline 26 & Curzerenone & $\mathrm{C}_{15} \mathrm{H}_{22} \mathrm{O}$ & 7,617 & 2,058 & 230.1307 \\
\hline 27 & Propanal & $\mathrm{C}_{15} \mathrm{H}_{20} \mathrm{O}_{2}$ & 7,621 & 0,919 & 232.1463 \\
\hline 28 & Turmeronol B & $\mathrm{C}_{15} \mathrm{H}_{20} \mathrm{O}_{2}$ & 7,624 & 2,504 & 232.1463 \\
\hline 29 & Dehydrocurdione & $\mathrm{C}_{15} \mathrm{H}_{22} \mathrm{O}_{2}$ & 7,825 & 1,204 & 234.1620 \\
\hline 30 & Procurcumenol & $\mathrm{C}_{15} \mathrm{H}_{22} \mathrm{O}_{2}$ & 7,828 & 2,804 & 234.1620 \\
\hline 31 & Isoprocurcumenol & $\mathrm{C}_{15} \mathrm{H}_{22} \mathrm{O}_{2}$ & 7,831 & 1,600 & 234.1620 \\
\hline 32 & Germacrone 4,5 epoxide & $\mathrm{C}_{15} \mathrm{H}_{22} \mathrm{O}_{2}$ & 7,834 & 1,350 & 234.1620 \\
\hline 33 & Curcumenol & $\mathrm{C}_{15} \mathrm{H}_{22} \mathrm{O}_{2}$ & 7,974 & 1,911 & 234.1620 \\
\hline 34 & Curcumenone & $\mathrm{C}_{15} \mathrm{H}_{22} \mathrm{O}_{2}$ & 7,975 & 4,100 & 234.1620 \\
\hline 35 & Curdione & $\mathrm{C}_{15} \mathrm{H}_{24} \mathrm{O}_{2}$ & 7,982 & 1,548 & 236.1776 \\
\hline 36 & Curcumol & $\mathrm{C}_{15} \mathrm{H}_{24} \mathrm{O}_{2}$ & 7,984 & 1,912 & 236.1776 \\
\hline 37 & 2methyl3cyclohexene 1,2 diol & $\mathrm{C}_{15} \mathrm{H}_{26} \mathrm{O}_{2}$ & 7,991 & 1,078 & 238.1933 \\
\hline 38 & Procurcumadiol & $\mathrm{C}_{15} \mathrm{H}_{22} \mathrm{O}_{3}$ & 7,995 & 1,434 & 250.1569 \\
\hline 39 & Zedoarondiol & $\mathrm{C}_{15} \mathrm{H}_{24} \mathrm{O}_{3}$ & 8,000 & 1,549 & 252.1725 \\
\hline 40 & Bisacurone & $\mathrm{C}_{15} \mathrm{H}_{24} \mathrm{O}_{3}$ & 8,002 & 0,790 & 252.1725 \\
\hline 41 & Quercetine & $\mathrm{C}_{15} \mathrm{H}_{10} \mathrm{O}_{7}$ & 11,427 & 2,155 & 302.0427 \\
\hline 42 & Bis Demethoxycurcumin & $\mathrm{C}_{19} \mathrm{H}_{16} \mathrm{O}_{4}$ & 11,505 & 2,277 & 308.1049 \\
\hline 43 & Demethoxycurcumin & $\mathrm{C}_{20} \mathrm{H}_{18} \mathrm{O}_{5}$ & 12,281 & 4,115 & 338.1154 \\
\hline 44 & Letestuianin A & $\mathrm{C}_{20} \mathrm{H}_{20} \mathrm{O}_{5}$ & 12,283 & 0,948 & 340.1311 \\
\hline 45 & Curcumin & $\mathrm{C}_{21} \mathrm{H}_{20} \mathrm{O}_{6}$ & 12,736 & 7,798 & 340.1311 \\
\hline 46 & Letestuianin B & $\mathrm{C}_{21} \mathrm{H}_{22} \mathrm{O}_{6}$ & 12,744 & 1,234 & 370.1416 \\
\hline 47 & Calebin A & $\mathrm{C}_{21} \mathrm{H}_{20} \mathrm{O}_{7}$ & 13,261 & 1,508 & 384.1209 \\
\hline 48 & $\beta$ Sitosterol & $\mathrm{C}_{29} \mathrm{H}_{50} \mathrm{O}$ & 17,163 & 2,230 & 414.3862 \\
\hline 49 & $\beta$ Carotene & $\mathrm{C}_{40} \mathrm{H}_{56}$ & 31,079 & 1,079 & 536.4382 \\
\hline
\end{tabular}


Tabel 2. Kandungan senyawa pada serbuk rimpang kunyit yang berpotensi sebagai antioksidan berdasarkan nilai Pa (Probability Activity)

\begin{tabular}{|c|c|c|c|}
\hline $\begin{array}{l}\text { Nomor } \\
\text { puncak }\end{array}$ & Nama senyawa & Rumus kimia & Nilai $P a$ \\
\hline 1 & $\rho$ Cymene & $\mathrm{C}_{10} \mathrm{H}_{16}$ & 0,144 \\
\hline 2 & $\alpha$ Terpinene & $\mathrm{C}_{10} \mathrm{H}_{16}$ & 0,135 \\
\hline 3 & $\alpha$ Pinene & $\mathrm{C}_{10} \mathrm{H}_{16}$ & - \\
\hline 4 & $\beta$ Pinene & $\mathrm{C}_{10} \mathrm{H}_{16}$ & - \\
\hline 5 & Sabinene & $\mathrm{C}_{10} \mathrm{H}_{16}$ & - \\
\hline 6 & Limonene & $\mathrm{C}_{10} \mathrm{H}_{16}$ & 0,157 \\
\hline 7 & $\alpha$ Phellandrene & $\mathrm{C}_{10} \mathrm{H}_{16}$ & - \\
\hline 8 & Camphene & $\mathrm{C}_{10} \mathrm{H}_{16}$ & - \\
\hline 9 & Cinnamic acid & $\mathrm{C}_{9} \mathrm{H}_{8} \mathrm{O}_{2}$ & 0,489 \\
\hline 10 & Arabinose & $\mathrm{C}_{5} \mathrm{H}_{10} \mathrm{O}_{5}$ & 0,801 \\
\hline 11 & Linalool & $\mathrm{C}_{10} \mathrm{H}_{18} \mathrm{O}$ & 0,380 \\
\hline 12 & $\alpha$ Terpineol & $\mathrm{C}_{10} \mathrm{H}_{18} \mathrm{O}$ & - \\
\hline 13 & Ascorbic acid & $\mathrm{C}_{6} \mathrm{H}_{8} \mathrm{O}_{6}$ & 0,951 \\
\hline 14 & Caffeic acid & $\mathrm{C}_{9} \mathrm{H}_{8} \mathrm{O}_{4}$ & 0,611 \\
\hline 15 & Fructose & $\mathrm{C}_{6} \mathrm{H}_{12} \mathrm{O}_{6}$ & - \\
\hline 16 & Glucose & $\mathrm{C}_{6} \mathrm{H}_{12} \mathrm{O}_{6}$ & - \\
\hline 17 & Heptan 3 one & $\mathrm{C}_{12} \mathrm{H}_{18} \mathrm{O}_{2}$ & - \\
\hline 18 & Curcumene & $\mathrm{C}_{15} \mathrm{H}_{22}$ & 0,303 \\
\hline 19 & $\beta$ Caryophyllene & $\mathrm{C}_{15} \mathrm{H}_{24}$ & 0,174 \\
\hline 20 & sesquiphellandrene & $\mathrm{C}_{15} \mathrm{H}_{24}$ & 0,213 \\
\hline 21 & Ar Turmerone & $\mathrm{C}_{15} \mathrm{H}_{20} \mathrm{O}$ & 0,274 \\
\hline 22 & $\alpha$ Turmerone & $\mathrm{C}_{15} \mathrm{H}_{22} \mathrm{O}$ & - \\
\hline 23 & Bisacumol & $\mathrm{C}_{15} \mathrm{H}_{22} \mathrm{O}$ & 0,248 \\
\hline 24 & Curlone & $\mathrm{C}_{15} \mathrm{H}_{22} \mathrm{O}$ & 0,197 \\
\hline 25 & $\alpha$ Atlantone & $\mathrm{C}_{15} \mathrm{H}_{22} \mathrm{O}$ & - \\
\hline 26 & Curzerenone & $\mathrm{C}_{15} \mathrm{H}_{22} \mathrm{O}$ & 0,274 \\
\hline 27 & Propanal & $\mathrm{C}_{15} \mathrm{H}_{20} \mathrm{O}_{2}$ & - \\
\hline 28 & Turmeronol B & $\mathrm{C}_{15} \mathrm{H}_{20} \mathrm{O}_{2}$ & 0,383 \\
\hline 29 & Dehydrocurdione & $\mathrm{C}_{15} \mathrm{H}_{22} \mathrm{O}_{2}$ & - \\
\hline 30 & Procurcumenol & $\mathrm{C}_{15} \mathrm{H}_{22} \mathrm{O}_{2}$ & 0,147 \\
\hline 31 & Isoprocurcumenol & $\mathrm{C}_{15} \mathrm{H}_{22} \mathrm{O}_{2}$ & - \\
\hline 32 & Germacrone 4,5 epoxide & $\mathrm{C}_{15} \mathrm{H}_{22} \mathrm{O}_{2}$ & - \\
\hline 33 & Curcumenol & $\mathrm{C}_{15} \mathrm{H}_{22} \mathrm{O}_{2}$ & - \\
\hline 34 & Curcumenone & $\mathrm{C}_{15} \mathrm{H}_{22} \mathrm{O}_{2}$ & 0,145 \\
\hline 35 & Curdione & $\mathrm{C}_{15} \mathrm{H}_{24} \mathrm{O}_{2}$ & - \\
\hline 36 & Curcumol & $\mathrm{C}_{15} \mathrm{H}_{24} \mathrm{O}_{2}$ & - \\
\hline 37 & 2methyl 3cyclohexene 1,2diol & $\mathrm{C}_{15} \mathrm{H}_{26} \mathrm{O}_{2}$ & - \\
\hline 38 & Procurcumadiol & $\mathrm{C}_{15} \mathrm{H}_{22} \mathrm{O}_{3}$ & - \\
\hline 39 & Zedoarondiol & $\mathrm{C}_{15} \mathrm{H}_{24} \mathrm{O}_{3}$ & 0.133 \\
\hline 40 & Bisacurone & $\mathrm{C}_{15} \mathrm{H}_{24} \mathrm{O}_{3}$ & 0,220 \\
\hline 41 & Quercetine & $\mathrm{C}_{15} \mathrm{H}_{10} \mathrm{O}_{7}$ & 0,878 \\
\hline 42 & Bis Demethoxycurcumin & $\mathrm{C}_{19} \mathrm{H}_{16} \mathrm{O}_{4}$ & 0,685 \\
\hline 43 & Demethoxycurcumin & $\mathrm{C}_{20} \mathrm{H}_{18} \mathrm{O}_{5}$ & 0,654 \\
\hline 44 & Letestuianin A & $\mathrm{C}_{20} \mathrm{H}_{20} \mathrm{O}_{5}$ & 0,483 \\
\hline 45 & Curcumin & $\mathrm{C}_{21} \mathrm{H}_{20} \mathrm{O}_{6}$ & 0,643 \\
\hline 46 & Letestuianin B & $\mathrm{C}_{21} \mathrm{H}_{22} \mathrm{O}_{6}$ & - \\
\hline 47 & Calebin A & $\mathrm{C}_{21} \mathrm{H}_{20} \mathrm{O}_{7}$ & 0,464 \\
\hline 48 & $\beta$ Sitosterol & $\mathrm{C}_{29} \mathrm{H}_{50} \mathrm{O}$ & 0,177 \\
\hline 49 & $\beta$ Carotene & $\mathrm{C}_{40} \mathrm{H}_{56}$ & 0,823 \\
\hline
\end{tabular}




\section{KESIMPULAN}

Hasil analisis $L C-M S$ menunjukkan bahwa pada serbuk rimpang kunyit mengandung beberapa senyawa dengan konsentrasi yang bervariasi. Konsentrasi tertinggi adalah senyawa kurkumin jika dibandingkan dengan konsentrasi senyawa yang lain. Senyawa-senyawa pada serbuk rimpang kunyit yang berpotensi sebagai antioksidan berdasarkan nilai $\mathrm{Pa}$ adalah ascorbic acid, quercetin, $\beta$ carotene, arabinose, bis demethoxycurcumin, demethoxycurcumin, curcumin, caffeic acid, cinnamic acid, letestuianin A, dan calebin A.

\section{UCAPAN TERIMA KASIH}

Artikel ini merupakan bagian dari disertasi penulis pertama yang selama studi telah dibiayai oleh program beasiswa BPPDN, Direktorat Jenderal, Pendidikan Tinggi. Kementerian Riset, Teknologi dan Pendidikan Tinggi, Republik Indonesia.

\section{DAFTAR PUSTAKA}

Agarwal, A., A. Aponte-Mellado, B.J. Premkumar, A. Shaman, S. Gupta. 2012. The effects of oxidative stress on female reproduction: a review. Reproductive Biology and Endocrinology. 10:1-49.

Aggarwal, B.B., C. Sundaran, N. Malani, H. Ichikawa. 2006. Curcumin: The Indian Solid Gold. SVNY. 332:16-34.

Bruns, D.R., J.C. Drake, L.M. Biela. 2015. Nrf2 signaling and the slowed aging phenotype: evidence from long-lived models. Oxidative Medicine and Cellular Longevity. 1-15

Chattopadhyay, I., K. Biswas, U. Bandyopadhyay, R. K. Banerjee. 2004. Turmeric and curcumin: Biological actions and medicinal applications. Current Science. 87:44-50.

Gantait, A., T. Barman, P.K. Mukherjee. 2011. Validated method for Estimation of curcumin in turmeric powder. Indian Journal of Traditional Knowledge. 10(2):247-250.
Halliwell, B., J. M. C. Gutteridge. 2015. Free Radical in Biology Medicine $5^{\text {th }}$ Edition (preview). Oxford University Press. Oxford. United Kingdom.

Hamaguchi, T., K. Ono, M. Yamada. 2010. Review: curcumin and Alzheimer's disease. CNS. Neuroscience Therapeutic. 16:285-297.

Jockers, D. 2016. NrF2: The anti-oxidant amplifier. http://drjockers.com/nrf2-the-anti-oxidantamplifier/. Accessed on May $31^{\text {st }}$.

Kohli, K., J. Ali, M.J. Antasari, Z. Raheman. 2005. A Natural antiinflamatory agent. Edu. For. 37(3):141-143.

Li, S., W. Yuan, G. Deng, P. Wang, P. Yang, B.B. Aggarwal, 2011, Chemical composition and product quality control of turmeric (Curcuma longa L.), Pharmaceuti. Crops, 2:28-54

Lokhande, S.M., R.V. Kale, A.K. Sahoo, R.C. Ranveer. 2013. Effect of curing and drying methods on recovery, curcumin and essential oil content of different cultivars of turmeric (Curcuma longa L.). International Food Research Journal. 20(2):745-749.

Paramashivam S.K., K. Elayaperumal, B.B. Natarajan. 2015. In silico pharmacokinetica nd molecular docking studies of small molecules derived from Indigofera aspalathoides Vahl targeting receptor tyrosine kinases. Bioinformation. 11(2): 7384.

Purwaningsih, E., S. K. Soejono, D. Dasuki, E. Meiyanto. 2013. Sasaran Aksi Pentagamavunon-0 pada Steroidogenesis Sel Luteal Melalui Pengukuran Fosforilasi Extracellular Signal Regulated Kinase. Journal Indonesia Medicine Associates. 63(2):52-57.

Reyes, S.G., S.G. Beltrán., O.N. Campos, J.P. Chaverri. 2013. Curcumin Pretreatment Induces Nrf2 and an Antioxidant Response and Prevents Hemin-Induced Toxicity in Primary Cultures of Cerebellar Granule Neurons of Rats. Hindawi Publishing Corporation Oxidative Medicine and Cellular Longevity.

http://dx.doi.org/10.1155/2013/801418. 
Setyaningsih D., Y.B. Murti, S. Martono, W.L.J. Hinrichs, T. Hertiani, A. Fudholi. 2016. A novel reversed phase high performance liquid chromatography method to accurately determine low curcumin in rat plasma. International Journal of Pharmaceutical and Clinical. 8(5):377-386.

Shehzad, A., Y.S. Lee. 2010. Curcumin : Multiple molecular targets mediate multiple pharmacological actions : A review. Drugs. Fut. 35:113-120.

Shen, L. R., F. Xiao, P. Yuang, Y. Chen, Q. K. Gao. 2012. Curcumin-supplemented diets increase superoxide dismutase activity and mean lifespan in Drosophila. Age. DOI : 10.1007/s11357-012-9438-2. Published online in Wiley Online Library. wileyonlinelibrary.com.

Singh, G., I.P.S. Kapoor, P. Singh, C.S. de Heluani, M.P. de Lampasona, C.A.N. Catalan. 2010. Comparative study of chemical composition and antioxidant activity of fresh and dry rhizomes of turmeric (Curcuma longa Linn.). Food and Chemical Toxicology. 48:1026-1031.

Zhang, D.D. 2006. Mechanistic studies of the nrf2keap1 signaling pathway. Inform. Health. 38:769-789. 